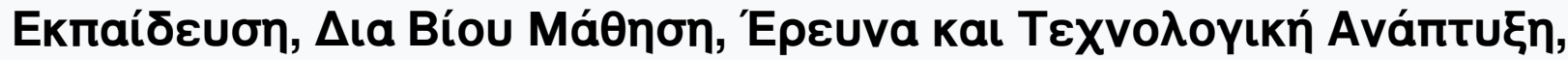 Katvotopía kal Oıкоvopía
}

Tóp. 1 (2016)

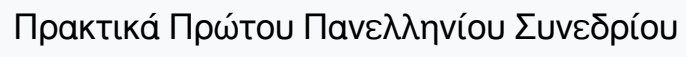

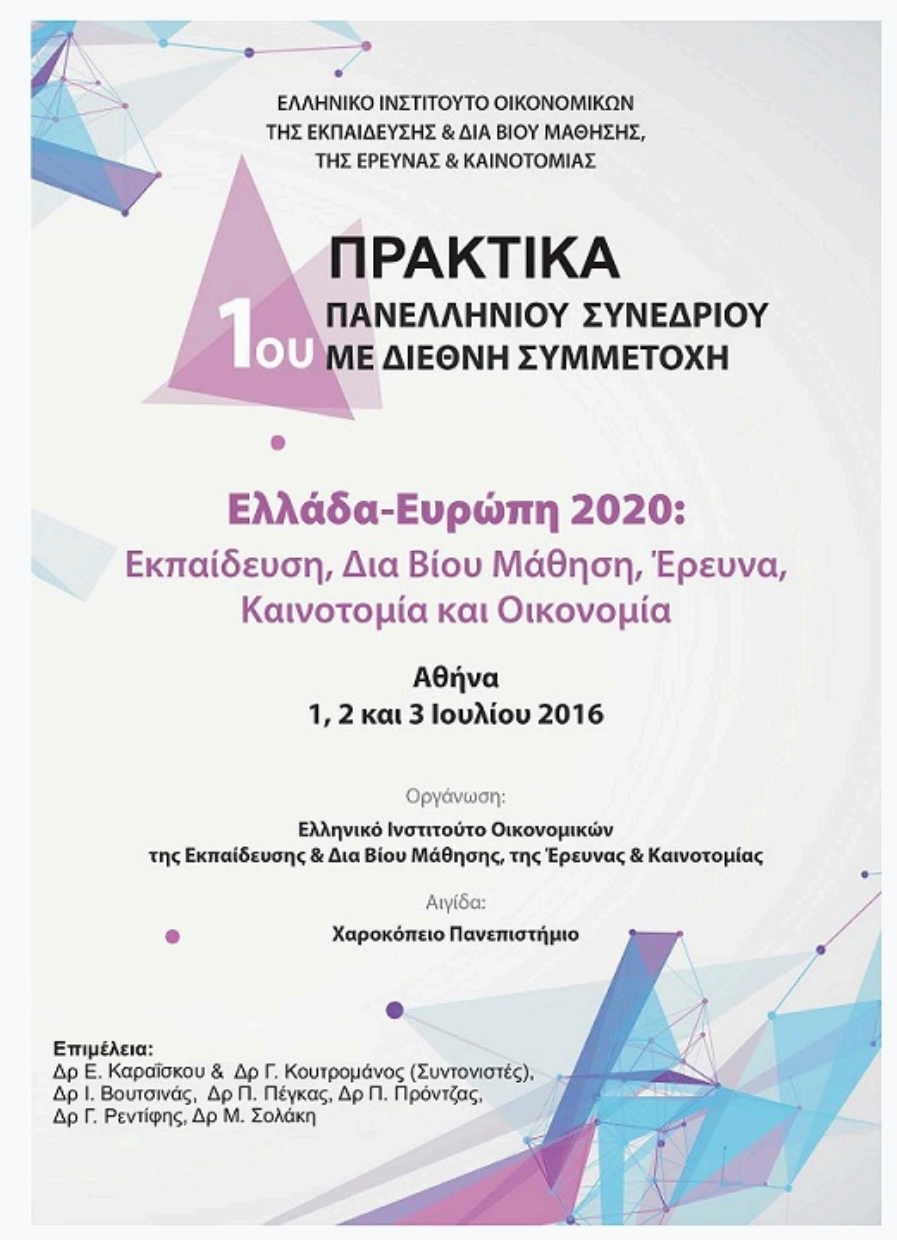

Adult Education and Economic Development

Pantelis Sklias, Giota Chatzimichailidou

doi: $10.12681 /$ elrie.797 


\title{
Adult Education and Economic Development
}

\author{
Pantelis Sklias $^{1}$, Giota Chatzimichailidou ${ }^{2}$ \\ psklias@hotmail.com, giotahatzi@gmail.com \\ ${ }^{1}$ Professor, ${ }^{2} \mathrm{PhD}$ Candidate
}

\begin{abstract}
In the present study, the issue under scrutiny is the contribution of adult education to economic development. The upgrading of adult education standards is seen as central to the delivery of European social cohesion and therefore to economic development. Adult education programs can enable the citizens to develop critical review and understanding of major contemporary problems of their lives, to reassess and interpret their experiences, and therefore to interact and communicate with other people and institutions. Transformative Learning Theory is such a tool for explaining this procedure. After all, future action will be planned: as citizens are presented with renewal ideas and patterns, they become more capable of forming and holding together the constituting parts of a cohesive European society towards economic development, together with other people and institutions.
\end{abstract}

Key words: adult education, economic development, social cohesion

\section{Introduction}

In this study, the discussion will seek to explore the potential contribution of adult education to economic development. We consider adult education to be development factor not only in weak and developing countries, as emphasized by the prevailing discourse since the early 1950s, but also in developed ones. In this paper the discussion revolves around the European Union. It is our strong belief that the development policies and efforts of the European Union may be heavily influenced by a European plan for promoting adult education programs in certain realms of today's political, social and economic life, such as: a) Domestic (Europeanwide) and international migration, b) Refugee crisis, c) Enhancing Democratic participation and active citizenship, d) Helping the weaker members of society, e) Tackling political extremism, f) Dealing with terrorism and the fear it spreads. Those adult education programs could serve as a means for eliminating a few disparities in the above realms, enhance social inclusion, and simultaneously empower citizens' action towards a cohesive society. It is of great importance that education should not be seen as a self-contained enterprise, but as a parameter in a complex context where adult education coexists and interacts with various realms of political, social and economic life (Sklias \& Chatzimichailidou, 2016).

Since the early 1950s, Brussels Bureaucrats seem to be excessively preoccupied with meeting the needs of European labour market, in order to stem the rise of unemployment in Europe. Hence, their efforts were mostly focused on promoting Vocational Education and Training instead of adult education. As a matter of fact, interest in the concepts of adult education first started to emerge in 2000 , along with the first extensive policies for strengthening European social cohesion through adult education and lifelong learning.

An analysis framework is proposed for the needs of this paper, which encapsulates the following perspectives:

- A brief historical reference framework of adult education policies in EU.

- A basic reference to Transformative Learning Theory.

- A definition of the term "social cohesion" 
- An analysis of the correlation between adult education and economic development.

\section{EU Policies Affecting Adult Education From 1950 Onwards}

In the following paragraphs we will try to unfold the history of official EU policy statements during the aforementioned period. The aim of this historical review is to elucidate whether references for adult education policies exist and in which extent. Prior to this analysis, we will discuss the definitions of the terms used in this paper.

\subsection{Defining Terms}

In our previous papers we raised the terminology issue, as there is obviously a variety of definitions in the literature. Current research appears to corroborate that view. Many studies use the term 'Lifelong Learning', while others use the terms 'Vocational Education and Training' and 'adult education' (Sklias \& Chatzimichailidou, 2016). Our concern is whether there is the best path to define those terms. This issue is further clouded by the fact that many studies seem to equate those terms. For example, Lifelong learning is mis-equated with Adult Education. In this paper we argue that adult education denotes the entire body of organized educational processes within the framework on non-formal education. The latter term was established in 1973 by Coombs and Ahmed, according to whom non-formal education refers to any organized educational activity that takes place outside the formal educational system (Rogers, 2005). Adult education covers the lifespan after the cessation of formal education, and serves both as a means of personal betterment and economic development (Sklias \& Chatzimichailidou, 2016). It is oriented at any age within adulthood and spotlights the ability of every adult to freely engage in educational processes. We identify as adult all persons who are considered to be adults by the society they belong to, and hold the ability to construe meaning from their experiences, to possibly revise some interpretations in order to plan future actions, and therefore to modify erroneous patterns or adopt new ones.

A careful study of the literature reveals that the first serious discussions about 'development' began after WWII, in an attempt to define the origins of poverty in the developing countries. Since then, this term has gone through a reconstruction process in regard to both its meaning and appliance: it gradually incorporated a 'qualitative' dimension that markedly differentiates this term from the term 'growth', which has a 'quantitative' dimension. Moreover, its scope has been expanded from developing countries to developed ones. Current research has indicated that there is no consensus view about what development means or what it implies (Sklias \& Chatzimichailidou, 2016). In this paper, we argue that economic development is both a process and a state. It is a process, as it involves the means by which a society can be transformed towards an improvement of human lives, and it is a state, as citizens feel more satisfied and secure, enjoy equal opportunities to work and have access to basic infrastructure. This is the state in which people wish to remain the longest. Lest the reader be led astray, we do not argue that economic development is separate from economic growth. Economic development declares a state in terms of growth, where measures like GDP per capita are also very useful (Sklias \& Chatzimichailidou, 2016). Sen suggests that development is 'a process of expanding the real freedoms that people enjoy' (Todaro \& Smith, 2012). Development is the process of improving the quality of all human lives and capabilities by raising people's levels of living, self-esteem, and freedom, as also highlighted by Todaro \& Smith (2012). Thirlwall (2001), identifies Goulet's work in broadening the notion of development in order to include economic and social objectives and values that every society strives for. Goulet (2002), connotes that development, as pursued by the dominant economy, means maximum 
economic growth, whereas what it ought to be pursued is qualitative human betterment. Moreover, Goulet (Thirlwall, 2001) distinguishes three basic components or values of development:

1. Life-sustenance,

2. Self-esteem,

3. And freedom.

\subsection{EU Policy Framework for Adult Education}

Adult education, either as an ideology or as a practice, hasn't gained widespread attention by the Brussels Bureaucrats; as a result, interest in the concepts of adult education emerged only in 2000. Adult education is mentioned for the first time as distinct part in Commission's working paper titled 'A Memorandum on Lifelong Learning' (CEC, 2000), called into a European cooperation 'Training courses and qualifications for education and training practitioners working in non-formal sectors (such as youth and community work), in adult education or in continuing training are underdeveloped everywhere in Europe. What can be done to improve this situation, including through European co-operation' (CEC, 2000).

According to Holford and Milana (2014), adult education was first recognized as a selfstanding policy area under the Grundtvig programme, a sub-programme that focused on adult education and other educational pathways. On March 23 and 24, 2001, the European Council met in Stockholm (Stockholm European Council, 2001) and the ministers for education agreed, for the first time, on a set of three strategic goals and thirteen concrete objectives, which became the basis of the 'Education and training 2010' process (Rasmussen, 2014). The objectives especially relevant to adult education, according to the same author, were: developing key competences, access to information, and communications technology for everyone; creating an open learning environment; promoting active citizenship, equal opportunities and social cohesion; and strengthening links among the labour market, research, and society. In 2006 the definition of adult learning became a matter of policy in a Communication from the Commission, titled 'adult learning: It is never too late to learn' (CEC, 2006). On November 15, 2006, the European Parliament and the Council released a decision establishing an action programme in the field of Lifelong Learning for the period 2007-2013. The term Adult Learning is now replaced by the term Adult Education. According to Article 2, 'adult education means all forms of non-vocational adult learning, whether of a formal, non-formal or informal nature'. It is the first time that this term acquires such a narrow definition.

Mention should also be made to the use of the term adult education in the Council Conclusions. The Council invited the Commission to 'strengthen and use existing research structures for the needs of adult education'. Member States were invited to promote and support the exchange of good practice with stakeholders, mutual learning, and the development of joint projects in the field of adult education and therefore to reinforce cooperation with CEDEFOP, the UNESCO Institute for Lifelong Learning and other international institutions, in the area of adult education and Learning (CEU, 2008). In 2011, the Council of the European Union recognized that all adults, included the high-qualified, can benefit from Lifelong Learning, especially in times of economic crisis (CEU, 2011). Later the Commission released a Communication titled 'Key competences for a changing world. Draft 2010 joint progress report of the Council and the Commission on the implementation of the Education \& Training 2010 work programme' and a staff working document titled 'Key competences for a changing world. Progress towards the Lisbon objectives in education and training. Analysis of implementation at the European and national levels'. Among the Key Competences is that adult education and training should provide all adults with real opportunities to develop and update their key competences throughout life. The 2012 Joint 
Report of the Council and the Commission on the implementation of the Strategic Framework for European cooperation in education and training (ET 2020) 'Education and Training in a smart, sustainable and inclusive Europe' proposed new working priorities for the period 20122014 geared to mobilise education and training to support Europe 2020 (European Commission, 2012). There is no reference to adult education, or to adult learning in this draft. Rasmussen (2014) stresses that EU activity and debate has mostly focused on urgent economic issues owing to the severe economic crisis that hit much of Europe shortly after the commencement of the Europe 2020 process. Therefore, this has had a profound impact on priorities in the field of education, including adult learning. Adult education has been excluded again as a matter of policy.

\section{A Basic Reference to Transformative Learning Theory}

Transformative learning is an adult learning theory first articulated by Jack Mezirow in the late 1970s. Central to the theory is the argument that what adults experience is a catalyst that causes them to question their worldview, which leads to a fundamental change in the way that they view the world (Di Biase, 2000). According to the Encyclopedia of the Sciences of Learning (Seel, 2012), transformational learning is the process of deep, constructive, and meaningful learning that goes beyond simple knowledge acquisition and supports critical ways in which learners consciously make meaning of their lives. Along similar lines, Dirkx (1998) identifies transformative learning as an ongoing, continuous process of re-constructing the meaning of our experience. Likewise, he continues that 'taken as narrative, this story reveals a sense of transformative learning as a heroic journey undertaken by a rational ego in pursuit of consciousness and enlightenment' (Dirkx, 1998). Since the publication of Mezirow's theory, many scholars critiqued and elaborated on the theory, leading to theoretical development in a variety of new perspectives. Dirkx suggests four different perspectives that have emerged from examining transformative learning theory: Daloz's developmental approach, Freire's emancipatory approach, Boyd's extrarational approach, and Mezirow's rational approach (Kucukaydin \& Cranton, 2012).

\section{Defining The Term 'Social Cohesion'}

Prior to any discussion of social cohesion, we should point out that the literature revealed a variety of definitions for this term. However, the available evidence suggests that social cohesion refers to the ways in which constituent groups or communities are linked together (Schuller et al., 2002), and is the property by which whole societies, and the individuals within them, are bound together through the action of specific attitudes, behaviours, rules and institutions (Janmaat \& Green, 2013). According to OECD (2011), a cohesive society works towards the well-being of all its members, fights exclusion and marginalisation, creates a sense of belonging, promotes trust, and offers its members the opportunity of upward mobility. On the basis of this evidence we argue that social cohesion strengthens respect for human rights and fundamental freedoms, such as security, self-esteem, democracy, well-being and access to basic infrastructure for all citizens (Sklias \& Chatzimichailidou, 2016). Adult education can to a great extent determine the identity and quality of social cohesion towards economic development (Sklias \& Chatzimichailidou, 2016). Lest the reader be led astray, we do not argue that adult education is itself a sufficiently strong parameter to strengthen the constituent parts of a European cohesive society, as it actually coexists with other parameters, 
and all of them participate effectively towards this process. Through adult education programs, individual actors, citizens, will be empowered to be part of the society's evolution towards social cohesion. Transformative Learning Theory is such a tool, i.e. the participants will be encouraged to develop critical views and understanding of major problems of their life, to reassess, reevaluate and interpret their experiences and thoughts, thus getting closer to new ideas, people and even institutions. In the long run, and according to the bibliography used above, this process will add a stone to the edifice of social cohesion.

\section{An Analysis Of The Correlation Between Adult Education And Economic Development}

As highlighted in the preface, adult education programs in certain realms of today's political, social and economic life in the EU might eliminate a few disparities in the above realms, enhance social inclusion, and simultaneously empower citizen action towards a cohesive society. Moreover, adult education could very much determine the identity and quality of social cohesion towards economic development (Sklias \& Chatzimichailidou, 2016). Adult education, especially in the light of the dominant Transformative Learning Theory, might be a useful channel for both eliminating any disparities in the above realms and simultaneously empowering citizen action towards social cohesion. Adult education, through the impact of Transformative Learning Theory, enables citizens to develop critical review and understanding of major contemporary problems of their life, to reassess and interpret their experiences and therefore to react and communicate with other people and institutions, and, consequently, future action will be planned. As a corollary, adult education will provide citizens with some patterns or help them to construct new patterns, which might be useful in order to react to future situations. Therefore, adult education develops the citizens' ability to participate effectively in the construction of a cohesive society, which consequently might contribute to the elimination of a few disparities in the political, social and economic realms. Hence, this is the state in which people wish to remain the longest, as they will enjoy equal opportunities to work and have access to basic infrastructure, improved human lives' quality, self-esteem and freedom which accordingly implies a transition to economic development.

\section{Conclusion}

The significance of this paper is the attempt to explore the potential contribution of adult education to economic development. Adult education and economic development strengthen one another. In this framework citizens play a vital role, as though adult education they will be empowered to be part of the society's evolution towards social cohesion. This is the state in which people wish to remain the longest, as they will enjoy equal opportunities to work and have access to basic infrastructure, improved human lives' quality, self-esteem and freedom which accordingly implies a transition to economic development. Further findings of this study will be presented in future papers. Considerably, more work will need to be done to determine the role of adult education to economic development. 


\section{References}

Commission of the European Communities (CEC). (2000) A Memorandum on Lifelong Learning. Available from:

http://arhiv.acs.si/dokumenti/Memorandum_on_Lifelong_Learning.pdf [Accessed 15th September 2016].

Commission of the European Communities (CEC). (2006) Adult learning: It is never too late to learn. Available from: http://eurlex.europa.eu/LexUriServ/LexUriServ.do?uri=COM:2006:0614:FIN:EN:PDF [Accessed 16th September 2016].

Council of the European Union (CEU). (2008) Council conclusions of 22 May 2008 on adult learning. Available from: http://eur-

lex.europa.eu/LexUriServ/LexUriServ.do?uri=OJ:C:2008:140:0010:0013:EN:PDF [Accessed 15th September 2016].

Council of the European Union (CEU). (2011) Council Resolution on a renewed European agenda for adult learning. Available from: http://eur-lex.europa.eu/legalcontent/EN/TXT/?uri=uriserv:OJ.C_.2011.372.01.0001.01.ENG [Accessed 15th September 2016].

Di Biase, W.J. (2000) Mezirow's Theory of Transformative Learning with Implications for Science Teacher Educators. Available from: http://files.eric.ed.gov/fulltext/ED452020.pdf [Accessed 11th September 2016].

Dirkx, J. M. (1998) Knowing the self through fantasy: Toward a mytho-poetic view of transformative learning. Proceedings of the 39th Annual Adult Education Research Conference, University of the Incarnate Word and Texas A \& M, San Antonio. Available from: http://www.adulterc.org/Proceedings/1998/98dirkx.htm [Accessed 11th September 2016].

European Commission. (2012) Education and Training in a smart, sustainable and inclusive Europe. Available from: http://eurlex.europa.eu/LexUriServ/LexUriServ.do?uri=COM\%3A2011\%3A0902\%3AFIN\%3AEN \%3APDF [Accessed 16th September 2016].

Goulet, D. (2002) What is a just economy in a globalized world? International Journal of Social Economics. 29 (1/2), 10-25.

Holford, J. \& Milana, M. (2014) Introduction: European Adult Education Policy in Question. In: Milana, M. \& Holford, J. (eds.) Adult Education policy and the European Union: theoretical and methodological perspectives. Rotterdam/Boston/Taipei, Sense Publishers, pp. 1-13.

Janmaat, J. G. \& Green, A. (2013) Skills Inequality, Adult Learning and Social Cohesion in the United Kingdom. British Journal of Educational Studies. 61 (1), 7-24.

Kucukaydin, I., \& Cranton, P. (2012) Critically Questioning the Discourse of Transformative Learning Theory. Adult Education Quarterly. 63(1), 43-56.

OECD. (2011) Perspectives on Global Development 2012: Executive summary. Available from: http://www.oecd.org/site/devpgd2012/49067839.pdf [Accessed 16th September 2016].

Rasmussen, P. (2014) Adult Learning Policy in the European Commission: Development and Status. In: Milana, M. \& Holford, J. (eds.) Adult Education policy and the European 
Union: theoretical and methodological perspectives. Rotterdam/Boston/Taipei: Sense publishers, pp. 17-34.

Rogers, A. (2005) Non-Formal Education. Flexible Schooling or Participatory Education? USA, Springer-Verlag US.

Seel, M.N. (2012) Encyclopedia of the Sciences of Learning. Springer New York Dordrecht Heidelberg London. Springer Science+Business Media, LLC 2012, pp. 3341-3344.

Schuller, T, Brassett-Grundy, A, Green, A, Hammond, C and Preston, J. (2002) Learning, Continuity and Change in Adult Life. London, Centre for Research on the Wider Benefits of Learning.

Sklias, P. \& Chatzimichailidou, G. (2016) Adult Education: A Vehicle for Economic Development. In: Karasavvoglou, A., Kyrkilis, D., Makris, G., Polychronidou, P. (eds.) Economic Crisis, Development and Competitiveness in Southeastern Europe. Switzerland, Springer International Publishing, pp. 139-157.

Stockholm European Council. (2001) Presidency conclusions and annexes. Available from: http://aei.pitt.edu/43341/ [Accessed 12th September 2016].

Thirlwall, A.P. (2001) Growth and Development. Athens, Papazisis Publishers (In Greek).

Todaro, M.P., Smith, S.C. (2012) Economic Development - 11th Edition. Boston, AddisonWesley. Available from: http://eco.eco.basu.ac.ir/BasuContentFiles/57/57304a77-12694081-bd5b-4c66b84b06a4.pdf [Accessed: 11th September 2016].

Pantelis Sklias (1969) is a Professor of International Political Economy (IPE) at the Department of Political Science and International Relations of the University of Peloponnese, Corinth Greece. He was also a visiting lecturer at the Department of International and European Studies of the University of Macedonia and visiting lecturer and assistant professor from 2002 to 2007 at the Department of International Economic Relations and Development of the Dimocritus University of Thrace. Since 2002, he has taught at the Hellenic Open University. From 1999 to 2002, he was a visiting research fellow at the Postgraduate Centre for Culture, Development and the Environment (CDE) of the University of Sussex. His research interests are related to the study of the International and European political economy and governance.

Giota Chatzimichailidou (1982) is a PhD Candidate at the Department of Political Science and International Relations of the University of Peloponnese. She writes a PhD thesis with the title "The contribution of Adult Education to Economic Development". Her research interests include Adult Education, International and European Political Economy, Development and Governance. 